\title{
The Effectiveness of Behavioral Counseling as Intervention of Abasement, Aggression, and Endurance of High School Students
}

\author{
(Keefektifan Konseling Behavioral sebagai Intervensi Sifat Abasement, Aggression, dan \\ Endurance Siswa Sekolah Menengah Atas) \\ I Ketut Gading* \\ Department of Guidance and Counseling, Faculty of Education, Universitas Pendidikan Ganesha, \\ Udayana Street No 11. Singaraja, Bali, 81116 Indonesia \\ *corresponding author, e-mail: iketutgading@undiksha.ac.id
}

Article received: August $26^{\text {th }} 2020$; revised: October $1^{\text {st }} 2020$; accepted: October $14^{\text {th }} 2020$

\begin{abstract}
This study aims to determine: (1) the effectiveness of behavioral counseling with assertive training techniques to increase the nature of abasement, (2) the effectiveness of behavioral counseling with shaping techniques to reduce the nature of aggression, and (3) the effectiveness of behavioral counseling with self-management techniques to increase the nature of endurance. This study employed an experimental study with a pre-test post-test control group. Participants involved were 37 class XI students of the Lab. School Undiksha. To recruit the participants, a purposive sampling technique was used by which the participants were students with low abasement, high aggression, and low endurance. Data were collected using scales that measure the nature of the abasement, aggression, and endurance. To test the hypothesis, the data were analyzed using the t-test. The results showed that: (1) behavioral counseling with assertive training techniques was effective for increasing the nature of abasement, (2) behavioral counseling with shaping techniques was effective to reduce the nature of aggression, and (3) behavioral counseling with self-management techniques was effective for increasing the nature of endurance.
\end{abstract}

Keywords: behavioral counseling; personality traits; abasement; aggression; endurance

\begin{abstract}
Abstrak: Penelitian ini bertujuan untuk mengetahui: (1) keefektifan konseling behavioral teknik latihan asertif untuk meningkatkan sifat abasement, (2) keefektifan konseling behavioral dengan teknik shaping untuk mereduksi sifat aggression, dan (3) keefektifan konseling behavioral dengan teknik selfmanagement untuk meningkatkan sifat endurance. Penelitian ini adalah penelitian eksperimen dengan desain penelitian pre-test post-test control group. Sampel atau partisipan penelitian ini adalah siswa kelas XI Sekolah Lab. Undiksha yang berjumlah 37 siswa. Teknik yang digunakan dalam penarikan subjek adalah purposive sampling, dalam hal mana siswa yang menjadi anggota sampel adalah siswa yang memiliki sifat abasement rendah, sifat aggression tinggi, dan sifat endurance rendah. Data dikumpulkan dengan skala pengukuran sifat abasement, skala pengukuran sifat aggression, dan skala pengukuran sifat endurance. Untuk menguji hipotesis, data dianalisis dengan menggunakan uji t. Hasil penelitian menunjukan bahwa: (1) konseling behavioral teknik latihan asertif efektif untuk meningkatkan sifat abasement, (2) konseling behavioral teknik shaping efektif untuk mereduksi sifat aggression, dan (3) konseling behavioral teknik self-management efektif untuk meningkatkan sifat endurance.
\end{abstract}

Kata kunci: konseling behavioral; sifat kepribadian; abasement; aggression; endurance 


\section{INTRODUCTION}

Problems are part of every human's life. Problems occur when reality does not match expectations. As a result, individuals are sad, stress, and even frustrated. The environmental situation around humans has an impact on human behavior. Every behavior produces a consequence that causes positive and negative feelings and thoughts (Fall, Holden, \& Marquis 2017; Laura, 2016). This happens to every individual, including individuals who are in their teens. At the formal education level, high school level is when individuals are at the stage of adolescent development. Adolescence is a critical transition from childhood to adulthood accompanied by dramatic changes in physical and mental characteristics and the social environment (Despina et al., 2020; Dulaney, Graupmann, Grant, Adam, \& Chen, 2018).

A preliminary study carried out at two public high schools in Singaraja on August 2, 2019 shows that many teenagers experience problems and lack knowledge and ability to solve problems. The records of student visits to the guidance and counseling room at the State Senior High School 1 Singaraja and Senior High School 2 Singaraja show that $70.6 \%$ of visits are related to handling problematic students. In general, the observations carried out at the two schools indicate that the problems experienced by students are low learning outcomes (17.58\%), coming late to school (12.06\%), skipping school days (15.07). \%), having disputes with teachers $(7.53 \%)$, family problems $(10.05 \%)$, romantic relationships (15.07\%), doing fights (12.56\%), and committing theft (10.05\%).

Previous research by Smith et al. (2018) found that adolescents at the age of 13-18 years tend to have behavioral problems such as relationships with peers, romance, family, and other problems as they are at a critical period of identity. Jiménez and Estévez (2017) uncovered that $29.5 \%$ of teenagers in Mexico experience bullying and verbal abuse by their schoolmates, $22.2 \%$ of teenagers in Mexico are involved in cases of physical violence, and 5.3\% of the total number of teenagers in Spain are victims of physical violence in their schools. This shows that the problems experienced during adolescence are very high and cannot be tolerated. Branje (2018) and Zinn et al. (2020) explained that the problems experienced during adolescence could cause other problems in adulthood and old development. Based on this, appropriate and accurate solutions are central to deal with adolescent problems.

Individuals can avoid problems if they can manage their time. This happens since personality is a concept that can explain all behavioral phenomena (Sucipto \& Saleh, 2019; Xu, Mellor, \& Read, 2017; Xu, Mellor, Xu, \& Duan, 2014). Murray (in Kovary, 2018; Xu et al., 2017) describes needs as a construct that shows the drive in the brain region that regulates various processes such as perception, thought, and action to change existing and unsatisfactory conditions. Murray (in Billstedt et al., 2016; Kovary, 2018) states that there are three categories of individual needs, namely: (1) needs in work attitude (endurance), (2) needs in social attitudes (abasement), and (3) needs in self-attitude (aggression). These three categories of individual needs are represented by their respective abasement, endurance, and aggression characteristics. These characteristics reflect the needs of the human personality (Kovary, 2018; Lundin et al., 2014; Murray, 2008; Xu et al., 2017).

The nature of abasement is the nature of admitting and apologizing for mistakes, obeying rules, and receiving punishment as a result of mistakes. The higher the abasement of the individual, the better the individual's personality profile, and vice versa (Rahayu, 2018; Syafruddin, Hutabarat, Novalina, \& Sinaga, 2016; Tuapattinaja \& Juliana, 2016). Endurance is a trait related to individual resilience in overcoming all obstacles in life. The higher the endurance characteristic of the individual, the better the individual's personality profile, and vice versa (Rahayu, 2018; Syafruddin et al., 2016; Tuapattinaja \& Juliana, 2016). Meanwhile, the nature of aggression is a form of negative self-resistance against unwanted or threatening situations by opposing or showing domination. High aggression will result in a bad personality profile, and vice versa (Rahayu, 2018; Syafruddin et al., 2016; Tuapattinaja \& Juliana, 2016).

The nature of abasement, the nature of endurance, and the nature of aggression must be at an ideal level so that individuals avoid problems. Diastuti et al. (2017) stated that $42 \%$ of students had problems because they had low abasement properties. Low abasement is indicated by the attitude of not accepting punishment for mistakes that have been committed, violating class time rules, and negatively fighting the teacher when given advice. Putra et al. (2018) stated that as many as $68 \%$ of their researched participants experienced problems as they had low endurance. Problems experienced include skipping school due to not doing assignments, experiencing excessive anxiety since schoolwork is difficult, and 
wanting to quit school since they feel unable to follow the learning process. Dharsana et al. (2019) argued that $44 \%$ of students had high aggression as indicated by the attitude of verbally attacking the teacher when being reprimanded, hitting classmates when disputing, and using objects to attack their friends. Individual personality profile reflected in the three traits needs to be treated in order to develop in an ideal or positive direction so that problems do not occur.

To change the three types of personality traits, counseling is needed that is able to focus on individual behavior. As explained by Murray (in Sucipto \& Saleh, 2019; Syafruddin et al., 2016), the nature of needs will appear in a behavior in order to meet these needs. Therefore, behavioral counseling is appropriate to modify individual needs behavior. Behavioral counseling views that problematic individuals have a tendency to respond to negative behavior from their environment. Maladaptive behavior also occurs due to misunderstandings in responding to the environment appropriately (Goldberg, Cho, \& Lin, 2019; Mntlangula, Khuzwayo, \& Taylor, 2017). Anchored by the works of Curry and Whitlock (2015), Grossman and Elder (2015), and Kurth et al. (2015), the present study formulates individual behavior as a result of learning, so that it can also be changed through manipulation and creating learning conditions. The nature of abasement was intervened through behavioral counseling with assertive training techniques. The nature of aggression was intervened with behavioral counseling using shaping techniques, and the nature of endurance was intervened with behavioral counseling with self-management techniques.

Previous research has shown that a number of counseling techniques in behavioral counseling groups are effective at intervening in several personality characteristics that are reflected in observable behavior. For instance, behavioral counseling services with self-management techniques can develop learning responsibility for class XI students at Senior High School Al-Azhar 3 Bandar (Monica \& Gani, 2016). Other studies have shown that behavioral counseling with modeling techniques is effective at minimizing the tendency of high school students' aggressive behavior (Gading, Nisa, \& Lestari, 2017).

The present study aims to investigate: (1) the effectiveness of behavioral counseling with assertive training techniques to increase the nature of abasement, (2) the effectiveness of behavioral counseling with shaping techniques to reduce aggression, and (3) the effectiveness of behavioral counseling with self-management techniques to increase endurance. By manipulating the three characteristics of the needs in the student's personality, it is expected that it can form an effective student personality. Through this personality, students can enact appropriate behavior.

\section{METHOD}

This study employed an experimental design with a pre-test post-test control group. Participants consisted of three groups, namely a sample group of class XI students of the Department of Social Sciences 3, a sample group of class XI students of the Department of Social Sciences 2, and a sample group of class XI students of the Department of Natural Sciences 4 from the Lab. School Undiksha. Each class consists of an experimental group and a control group, so there are three experimental groups and three control groups. The treatments were carried out separately to the first experimental group, the second experimental group, and the third experimental group. Pre-test and post-test were given to all experimental and control groups. For more details, the design is presented in Figure 1 which was adapted from Creswell (2012). In Figure 1, $\mathrm{E}$ is the experimental group, $\mathrm{O}$ is the observation, $\mathrm{C}$ is the control group, $\mathrm{X} 1$ is the behavioral counseling of assertive training techniques, $\mathrm{X} 2$ is the behavioral counseling of shaping techniques, and $\mathrm{X} 3$ is the behavioral counseling of the self-management technique.

$\begin{array}{ccccc}\text { Class XI Social Science 3 } & \text { E1 } & \text { O } & \text { X1 } & \text { O } \\ & \text { C1 } & \text { O } & - & \text { O } \\ \text { Class XI Social Science 2 } & \text { E2 } & \text { O } & \text { X2 } & \text { O } \\ & \text { C2 } & \text { O } & - & \text { O } \\ \text { Class XI Natural Science 4 } & \text { E3 } & \text { O } & \text { X3 } & \text { O } \\ & \text { C3 } & \text { O } & - & \text { O }\end{array}$

Figure 1. Pre-test Post-test Control Group Experimental Design 
Participants involved in this study were students of class XI consisting of nine classes. Four classes are the Natural Sciences group, four classes are the Social Sciences group, and one class is the Language group. Each class consists of 30-35 students. They were recruited using both random dan purposive sampling techniques. The random technique was used to select classes from nine classes of population members to three classes of sample members. Purposive sampling technique was used to select sample members from population members who have personality traits with low abasement, high aggression, and low endurance. The sample was taken by randomly selecting three classes from nine classes of population members. From the results of random selection using a lottery technique, it was found that the class members of the sample were students of class XI Social Sciences 3, class XI Social Sciences 2, and class XI Natural Sciences 4. The samples from each class were reduced as follows: (1) to find out whether behavioral counseling with assertive training techniques is effective in improving the personality traits of abasement, the participants of this study were students of class XI Social Sciences $3 \mathrm{Lab}$. School Undiksha who have low personality traits, (2) to identify whether behavioral counseling with shaping training techniques is effective in minimizing aggression personality traits, the participants were students of class XI Social Sciences 2 who have high aggression personality traits, and (3) to find out whether behavioral counseling with self-management techniques is effective for improving endurance personality traits, the participants were students of class XI Natural Sciences 4 who have low endurance personality traits.

In determining the level of personality traits that are the dependent variable in this study, the actual average number parameter was used. If the student's score on the scale used to measure personality traits used as the dependent variable in this study is below the actual average, then the student is categorized as having low personality traits. Meanwhile, suppose the student's score in the questionnaire used measuring the personality traits that are used as the dependent variable in this study are above the actual average number. In that case, the student is categorized as having high personality traits. In this regard, a total sample of 37 students was obtained, which were divided into three groups, namely: (1) 10 students with low abasement, (2) 11 students with high aggression, and (3) students who had high aggression. have low endurance as many as 16 people.

Three instruments were used, namely: (1) the scale of measuring abasement, (2) the scale of measuring aggression, and (3) the scale of measuring the nature of endurance. Each scale has 30 statement items. Each scale has gone through a process of content validity and reliability testing. The content validity test was carried out through item analysis and expert judgment, while the reliability test was carried out by using Cronbach's Alpha analysis. The results of the item analysis show that all statement items on each scale have a critical value of 0.3 , which is the rejection limit for the $r$ product moment values, and this means that all items are valid. The results of the content validity test with expert judgment got the value of each scale is 1.0 , which means the validity is very high. The reliability test showed a value of 0.927 for the scale of measuring the nature of abasement, a value of 0.868 for the scale of measuring aggression, and 0.908 for the scale of measuring the nature of the endurance. Based on this value, it is known that all scales have very high-reliability values.

Data in this study were collected by distributing a research instrument in the form of a personality trait measurement scale to all population members. Furthermore, the participants' answers were analyzed to determine the level of each personality trait possessed by each respondent. The data analysis used to test the hypothesis in this study was the independent sample t-test. Data analysis was performed with the help of SPSS 24.0 for Windows.

\section{RESULTS}

\section{Behavioral Counseling using Assertive Exercise Techniques to Improve Abasement Traits}

The comparison of the pre-test and post-test of the experimental group and the control group for the abasement properties is presented in Table 1. The experimental group's mean value for the abasement trait after treatment is 132 or an increase of 20.6 points compared to the average pre-test score. In contrast to the control group, the mean score of the control group for abasement variables was relatively unchanged. The data in Table 1 show that the mean post-test for the abasement variable is 95.2 or unchanged from the mean pre-test score. 
Table 1. Scores of the Pre-test and Post-test Abasement Properties

\begin{tabular}{cccccc}
\hline \multicolumn{3}{c}{ Experiment Group } & \multicolumn{3}{c}{ Control Group } \\
\hline Participants & Pre-test & Post-test & Participants & Pre-test & Post-test \\
1 & 103 & 147 & 6 & 114 & 115 \\
2 & 117 & 131 & 7 & 114 & 114 \\
3 & 119 & 139 & 8 & 65 & 67 \\
4 & 113 & 122 & 9 & 65 & 60 \\
5 & 105 & 123 & 10 & 118 & 120 \\
Total & 557 & 662 & Total & 476 & 476 \\
Mean & 111.4 & 132 & Mean & 95.2 & 95.2 \\
\hline
\end{tabular}

Table 2. Data Analysis for Variable Abasement Properties

\begin{tabular}{|c|c|c|c|c|c|c|c|c|c|c|}
\hline \multicolumn{11}{|c|}{ Independent Samples Test } \\
\hline & & \multicolumn{2}{|c|}{$\begin{array}{l}\text { Levene's Test } \\
\text { for Equality of } \\
\text { Variances }\end{array}$} & \multicolumn{7}{|c|}{ t-test for Equality of Means } \\
\hline & & \multirow[t]{2}{*}{$\mathrm{F}$} & \multirow[t]{2}{*}{ Sig. } & \multirow[t]{2}{*}{$\mathrm{t}$} & \multirow[t]{2}{*}{$\mathrm{df}$} & \multirow[t]{2}{*}{$\begin{array}{c}\text { Sig. } \\
\text { (2-tailed) }\end{array}$} & \multirow[t]{2}{*}{$\begin{array}{c}\text { Mean } \\
\text { Difference }\end{array}$} & \multirow[t]{2}{*}{$\begin{array}{l}\text { Std. Error } \\
\text { Difference }\end{array}$} & \multicolumn{2}{|c|}{$\begin{array}{l}95 \% \text { Confidence } \\
\text { Interval of the } \\
\text { Difference }\end{array}$} \\
\hline & & & & & & & & & Lower & Upper \\
\hline \multirow[t]{2}{*}{ Result } & $\begin{array}{l}\text { Equal } \\
\text { variances } \\
\text { assumed }\end{array}$ & 20.738 & 0.002 & 2.681 & 8 & 0.028 & 37.2000 & 13.87444 & 5.20549 & 69.19451 \\
\hline & $\begin{array}{l}\text { Equal } \\
\text { variances } \\
\text { not } \\
\text { assumed }\end{array}$ & & & 2.681 & 5.054 & 0.043 & 37.2000 & 13.87444 & 1.64842 & 72.75158 \\
\hline
\end{tabular}

Furthermore, the data in Table 1 were analyzed for hypothesis testing using t-test analysis. The analysis is presented in Table 2. Based on the analysis in Table 2, the Sig. Levene's Test for Equality of Variances is $0.002<0.05$, meaning that the data variance between the experimental group and the control group is not homogeneous. Since the data are not homogeneous, data interpretation is guided by the values contained in the Equal variances not assumed column. Sig value. (2-tailed) on the t-test for equality of means in the Equal variances not assumed column shows a value of $0.043<0.05$, then the hypothesis is accepted. Thus, it can be seen that the behavioral counseling of shaping techniques is effective in increasing the nature of student abasement.

\section{Behavioral Counseling Shaping Techniques to Reduce Aggression Traits}

The comparison of the pre-test and post-test of the experimental group and the control group for the nature of the aggression is presented in Table 3. In Table 3, the mean value of the experimental group for the variable aggression after treatment is 115.6 or decreased by 18.6 points compared to the average pre-test score. In contrast to the control group, the mean score of the control group for the variable aggression properties was relatively unchanged. The data in Table 3 show that the average post-test for the variable aggression trait is 144 or decreased only 2.7 points from the average pre-test score. This score is relatively the same as the decrease is not significant. The data recapitulation of the pre-test and post-test scores is presented in Table 3.

Furthermore, the data in Table 3 were analyzed for hypothesis testing using t-test analysis. The analysis is presented in Table 4. Based on the analysis in Table 4, it is observed that the Sig. Levene's Test for Equality of Variances is $0.022<0.05$, meaning that the data variance between the experimental group and the control group is not homogeneous. Since the data are not homogeneous, data interpretation is guided by the values contained in the Equal variances not assumed column. Meanwhile, Sig. (2-tailed) 
Table 3. Scores of the Pre-test and Post-test Aggression Properties

\begin{tabular}{cccccc}
\hline \multicolumn{3}{c}{ Experiment Group } & \multicolumn{3}{c}{ Control Group } \\
\hline Participants & Pre-test & Post-test & Participants & Pre-test & Post-test \\
11 & 125 & 117 & 16 & 156 & 141 \\
12 & 123 & 118 & 17 & 144 & 148 \\
13 & 144 & 109 & 18 & 157 & 159 \\
14 & 150 & 120 & 19 & 134 & 129 \\
15 & 129 & 114 & 20 & 156 & 161 \\
& & & 21 & 133 & 126 \\
Total & 671 & 578 & Total & 880 & 864 \\
Mean & 134.2 & 115.6 & Mean & 146.7 & 144 \\
\hline
\end{tabular}

Table 4. Data Analysis for Variable Aggression Properties

\begin{tabular}{|c|c|c|c|c|c|c|c|c|c|c|}
\hline \multicolumn{11}{|c|}{ Independent Samples Test } \\
\hline & & \multicolumn{2}{|c|}{$\begin{array}{l}\text { Levene's } \\
\text { Test for } \\
\text { Equality of } \\
\text { Variances }\end{array}$} & \multicolumn{7}{|c|}{ t-test for Equality of Means } \\
\hline & & \multirow[t]{2}{*}{$\mathrm{F}$} & \multirow[t]{2}{*}{ Sig. } & \multirow[t]{2}{*}{$\mathrm{t}$} & \multirow[t]{2}{*}{ df } & \multirow[t]{2}{*}{$\underset{\text { (2-tailed) }}{\text { Sig. }}$} & \multirow[t]{2}{*}{$\begin{array}{c}\text { Mean } \\
\text { Difference }\end{array}$} & \multirow[t]{2}{*}{$\begin{array}{l}\text { Std. Error } \\
\text { Difference }\end{array}$} & \multicolumn{2}{|c|}{$\begin{array}{l}95 \% \text { Confidence } \\
\text { Interval of the } \\
\text { Difference }\end{array}$} \\
\hline & & & & & & & & & Lower & Upper \\
\hline \multirow[t]{2}{*}{ Result } & $\begin{array}{l}\text { Equal } \\
\text { vari- } \\
\text { ances } \\
\text { assumed }\end{array}$ & 7.668 & 0.022 & -4.129 & 9 & 0.003 & -28.4000 & 6.87809 & -43.95932 & -12.84068 \\
\hline & $\begin{array}{l}\text { Equal } \\
\text { vari- } \\
\text { ances } \\
\text { not } \\
\text { assumed }\end{array}$ & & & -4.495 & 5.984 & 0.004 & -28.4000 & 6.31876 & -43.87150 & -12.92850 \\
\hline
\end{tabular}

on the t-test for equality of means shows a value of $0.004<0.05$, it can be seen that the hypothesis is accepted. Thus, it can be seen that the behavioral counseling of shaping techniques is effective in reducing the nature of aggression.

\section{Behavioral Counseling Self-Management Techniques to Improve Endurance Traits}

The comparison of the pre-test and post-test results of the experimental group and the control group for the Endurance trait variable is presented in Table 5. In Table 5, the average value of the experimental group for the endurance trait variable after treatment is 120.5 or an increase of 16.75 points compared to the average score pre-test. In contrast to the control group, the mean score of the control group for the variable endurance trait was relatively unchanged. The data in Table 5 show that the post-test average for the Endurance trait variable is 144.2 or an increase of only 4.62 points from the average pre-test score. This score can be said to be relatively the same because the increase is not significant. Furthermore, the data in Table 5 were analyzed for hypothesis testing using t-test analysis. The analysis is presented in Table 6.

Based on the data in Table 6, the Sig value results are obtained. Levene's Test for Equality of Variances is $0.453>0.05$, which means that the data variance between the experimental group and the control group is homogeneous. Since the data are homogeneous, data interpretation is guided by the value contained in the Equal variances assumed column. Meanwhile, Sig. (2-tailed) on the t-test for equality of means shows a value of $0.001<0.05$, then the hypothesis is accepted. Thus, it can be seen that behavioral counseling is effective in increasing students' endurance properties. 
Table 5. Scores of the Pre-test and Post-test Endurance Properties

\begin{tabular}{cccccc}
\hline \multicolumn{3}{c}{ Experiment Group } & \multicolumn{3}{c}{ Control Group } \\
\hline Participants & Pre-test & Post-test & Participants & Pre-test & Post-test \\
22 & 80 & 119 & 30 & 111 & 113 \\
23 & 109 & 120 & 31 & 114 & 117 \\
24 & 107 & 123 & 32 & 113 & 118 \\
25 & 109 & 123 & 33 & 111 & 117 \\
26 & 107 & 119 & 34 & 112 & 118 \\
27 & 96 & 119 & 35 & 98 & 106 \\
28 & 113 & 127 & 36 & 110 & 112 \\
29 & 109 & 124 & 37 & 111 & 116 \\
\hline Total & 830 & 964 & Total & 880 & 917 \\
\hline Average & 103.75 & 120.5 & Average & 110 & 114.62 \\
\hline
\end{tabular}

Table 6. Data Analysis for Variable Endurance Traits

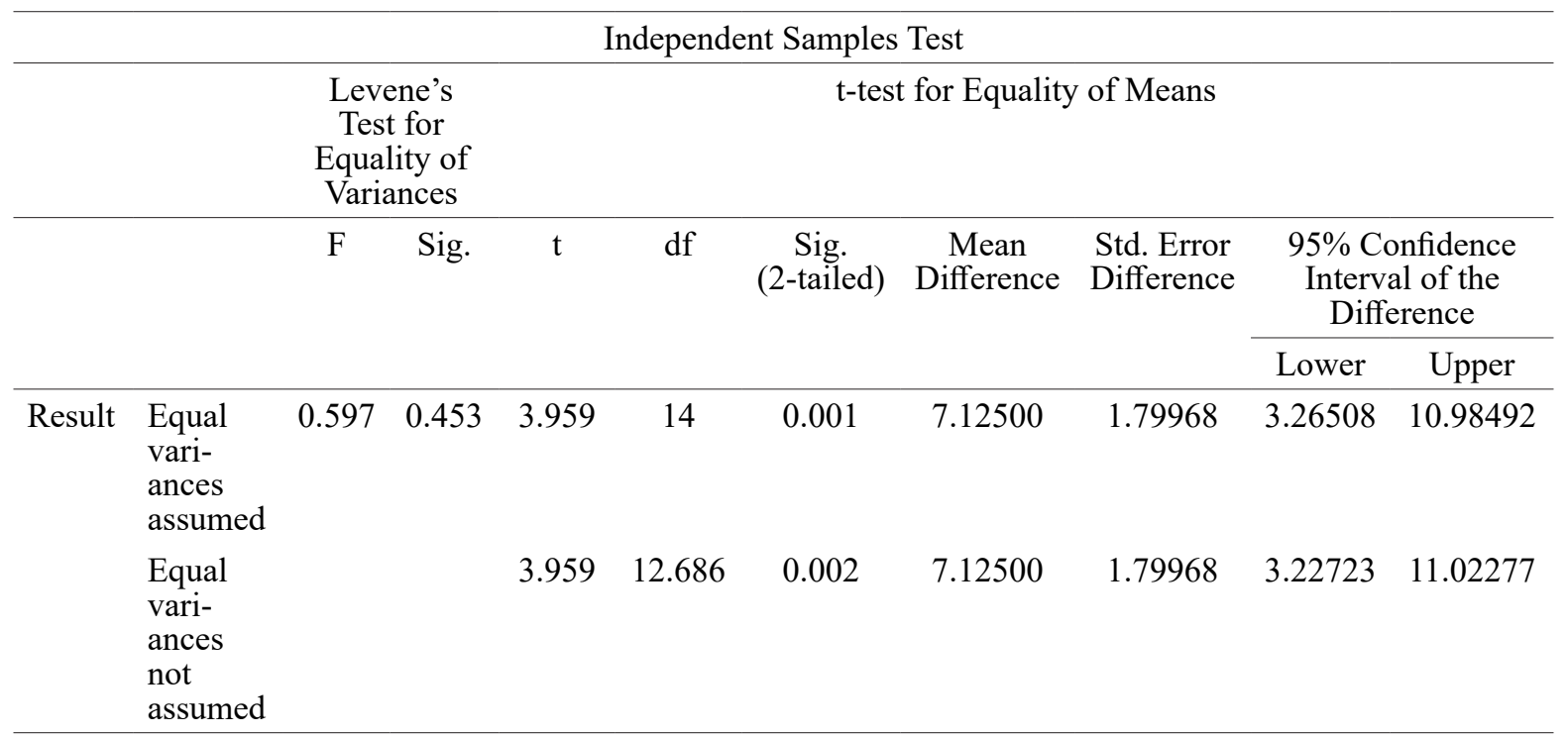

\section{DISCUSSION}

This study aims to determine the effectiveness of behavioral counseling as an intervention for the nature of abasement, aggression, and endurance. Treatment in the form of behavioral counseling was given in a group setting. A total of 18 participants were given intervention, and 19 students were in the control group. There were 3 intervention groups and 3 control groups. Each group was given different interventions for different variables. Based on the analysis, behavioral counseling is effective in increasing the nature of abasement, endurance, and reducing student aggression. This can be seen through the significant difference between the post-test scores of the intervention group and the control group, where the intervention group had a higher score than the control group score. In the intervention group, the post-test score of abasement and endurance was significantly increased compared to the pre-test score. Meanwhile, in the control group, the scores at the pre-test and post-test were relatively unchanged. This means that if there is a change, it is not significant as there is only an increase or decrease in a few points. In the nature of the aggression, there was also a significant difference between the scores of the intervention group and the scores of the control group. The students' post-test scores on the aggression nature increased significantly compared to the pre-test scores in the intervention group. Meanwhile, in the control group, post-test scores and pre-test scores were relatively unchanged. 


\section{Assertive Behavioral Counseling Technique to Improve Abasement Traits}

The results showed that the assertive technique was effective in increasing students' abasement properties. This is because assertive techniques train the participants to convey or express their ideas, interests, and emotions without hurting others' feeling. Assertive is a personality trait and communication style (Pfafman, 2017). Being assertive means being able to act based on self-concept by considering other people's points of view so that the behavior that appears remains within positive boundaries. In addition to communicating thoughts and feelings positively, individuals with assertiveness can also control their actions and accept responsibility for themselves (Parray \& Sanjay, 2017; Wahyu \& Muslikah, 2019).

The behavior that arises from the results of this intervention is that students could identify based on other people's point of view, students become easy to interact with peers, and are able to express sensitivity or concern about their peers' problems. Meanwhile, the nature of abasement is an individual characteristic to admit and apologize for mistakes, obey the rules, and accept punishment as a result of mistakes made (Kovary, 2018; Murray, 2008). This attitude is needed for individuals to be able to be passive, gentle, humble, and not anarchist react to threats (Murray, 2008). The implementation of assertive techniques that have been done can significantly form a passive attitude, gentle, humble, and do not react to anarchist threats. This can be seen from students' attitude who communicate apologies when making mistakes, receiving punishment when making mistakes without taking resistance either verbally or nonverbally. Students also look orderly when implementing learning in class after receiving counseling with assertive techniques.

In line with the research conducted by Paeezy et al. (2010) who found that assertive techniques can improve individual well-being, being able to tolerate various decisions and other people's behavior is one of the characteristics of well-being. In addition, being able to care about other people's point of view is one of the attitudes that are formed on the impact of individual well-being (Itahashi et al., 2020; Kahya \& Raspin, 2017; Paeezy et al., 2010; Sucipto \& Saleh, 2019). In line with this study, the results show that the nature of abasement is formed through tolerance for others' viewpoint, deep interaction with others, and sensitivity and concern for peers for the results of assertive training. The concept of assertive training starts from getting used to expressing the participants' ideas, interests, and emotions without hurting the feelings of others. Research by Niusha et al. (2012), Fuspita et al. (2018), and Omura et al. (2017) explained that assertive training is able to accustom individuals to not think negatively about others or on other participants. In line with this study, the nature of abasement is formed due to positive assessments of others so that individuals have the willingness to follow a different point of view from themselves.

The difference between the results of this study and the results of other studies is that this study can increase the nature of humility which leads to increasing the abasement nature of the research subject. This is one of the advantages of this research. Several other studies (Akbar et al., 2020; Prabowo \& Asni, 2018) show that assertive techniques improve communication skills in conveying thoughts, opinions, and feelings, not to follow and tolerate other people's points of view. This has the potential for individuals to fight or contradict rules or situations that are against the individual.

\section{Behavioral Counseling Shaping Technique to Reduce Aggression Traits}

The results showed that shaping techniques were effective in reducing students' aggression properties. The nature of aggression is gradually reduced according to the implementation of shaping techniques. Every change that has been shown by students is given reinforcement in the form of praise and warm behavior from counselors and class teachers. Murray (2008) explains the nature of aggression as a form of negative self-resistance to unwanted or threatening situations by opposing or showing domination. In a bad psychological condition, behavior s that arise due to the nature of aggression are verbal and nonverbal attacks, blaming, accusing, or at a very high level of aggression, behavior can lead to criminal acts. The nature of aggression arises from students because of the threats that they respond to excessively (Benjamin, 2016; Billstedt et al., 2016; Warburton \& Anderson, 2015). The decline in aggression's nature is carried out gradually, starting from eliminating negative thoughts and feelings, negative verbal behavior, and finally, negative nonverbal behavior such as physical assault. Each change is given reinforcement in the form of warm behavior and praise from the counselor and class teacher. Until finally, the overall nature of aggression can be reduced. Changes that occur are the ability to behave 
according to the needs of the existing situation. As described by Murray (2008), Xu et al. (2014), Lundin et al. (2014), Billstedt et al. (2016) that the nature of aggression cannot be reduced constantly. Change occurs gradually, and every change should be given the appreciation in the form of reinforcement.

This study's results are in line with the previous research by Michelle et al. (2016) who found the results that shaping techniques can reduce children's anxiety. The behavior changes gradually starting from the first day of giving intervention. The child's facial expression does not show anxiety when his parents leave him, the next day the child starts to behave normally but is still a little restless. Thus, the next day the behavior gets better. In this study, each change is also given a reward to strengthen the behavior that appears. The next relevant research is research conducted by Sarifa and Mahanani (2017) who found that shaping techniques can improve on-task behavior. Before forming on-task behavior, the participants' behavior leads to aggression towards their peers, such as disturbing colleagues who are working on tasks. Behavior can be reduced by accompanying the subject while doing the task. Rewards are given when each task is completed. In the following days, the increase in on-task behavior continued to increase to the expected behavior.

\section{Behavioral Counseling Self-Management Techniques to Improve Endurance Traits}

The results of this study indicate that self-management techniques are effective in improving students' endurance properties. Self-management is a behavior change strategy in which the counselee directs his own behavior change with a technique or combination of therapeutic techniques. Selfmanagement aims to help the counselee change negative behavior and develop positive behavior by observing oneself by noting certain behavior s (thoughts, feelings, and actions) and their interactions with environmental events (Grady \& Gough, 2018; Jonkman et al., 2016). Meanwhile, the nature of endurance is individual resilience in overcoming all obstacles in life (Billstedt et al., 2016; Lundin et al., 2014; Murray, 2008; Xu et al., 2017). The low endurance experienced by students is caused by a lack of self-control in facing problems. When a problem approaches, students tend to give up quickly and want to run away from the problem. As a result, problems are not resolved and affect other aspects of student life. Researchers use self-management techniques to train students to be able to manage themselves when experiencing a problem. Self-management is a behavioral counseling technique based on learning theory designed to develop students in controlling and changing their behavior (Grady \& Gough, 2018; Jonkman et al., 2016; Villaggi et al., 2015). Through self-management techniques, students are trained to control and change their behavior through self-control.

Self-management techniques have succeeded in improving students' endurance properties because the purpose of this technique is to teach students to manage themselves. So, they can think in advance when going to run from problems or give up on difficult situations. With self-management techniques, counselors teach students to identify every thought and behavior to be applied slowly, gradually and continuously so that students can get used to self-control. Because something that is done continuously will become a habit for these students. This is in accordance with the perspectives of Fahmi et al. (2019), Grady and Gough (2018), Jonkman et al. (2016), and Boger et al. (2015) which state that selfmanagement refers to an individual's ability to manage himself. Through adequate self-management, students gradually have resilience in dealing with any problems they experience. In line with the improvement of student self-management, the nature of endurance also increases. Thus, students become individuals who are resilient in overcoming all problems in their life.

The results of this study are in line with the previous research conducted by Fahmi et al. (2019), who found the results that self-management was able to improve students' self-control. Fahmi found that good self-management can become self-control for every individual thoughts and behavior. Through this, the desired behavior can be formed. Elvina (2019) found that self-management can form an effective person through gradual self-management. In his research, it was explained that an effective person could be started from managing yourself to obeying a schedule that has been arranged by yourself. Through good self-management, the participants' feelings become more positive because they have a daily activity that matches expectations. The relevance of the two previous studies with this research is that both form and train self-management of the subject to achieve the objectives of the study. 
The results of this study can be a reference for school counselors in conducting counseling activities in schools. Through the results of this study, behavioral counseling techniques can be applied to other variable interventions that are similar to this research variable. For other researchers, the results of this study can be used as a reference in intervening for Henry Murray's other needs variables. The results of this study indicate that the characteristics of individual needs can be increased and decreased according to the characteristics of each of these traits. The nature of needs in humans has a very important role in forming an effective personality so that it can be used as a reference for future researchers in providing interventions for other personality variables.

This study used a pre-test post-test control group design so that researchers can only measure and assess the results of the treatment that has been done for each variable with one measurement. It has become the limitation of this study as the researchers cannot determine the impact from the intervention that has been done since the measurement of the change in the dependent variable is only done once immediately after the treatment is given. Future research is recommended to use a time-series research design to measure and assess changes in the variables given treatment in stages so that the impact of the treatment can be known. Another research design that can be used is the single-subject design. Through this design, researchers can determine changes from the subject individually so that the findings are more accurate.

\section{CONCLUSION}

This study revealed that: (1) behavioral counseling with assertive techniques was effective for increasing students' abasement, (2) behavioral counseling with shaping techniques was effective to reduce students' aggression properties, and (3) behavioral counseling with self-management techniques was effective for improving students' endurance traits. These findings indicate that some of the student's personality traits can be modified through behavioral counseling techniques. The ideal level of abasement, aggression, and endurance could form an effective personality. It is suggested that school counselor or other parties who wish to intervene some personality traits, especially personality traits of abasement, aggression, and endurance, use behavioral counseling by selecting relevant techniques students' personality traits.

\section{ACKNOWLEDGEMENT}

Special thanks are addressed to the principal, school counselor, and high school students of the Lab. School Undiksha who have helped carry out this research.

\section{REFERENCES}

Akbar, N. Y., Wangid, M. N., \& Prawitasari, G. (2020). Keefektifan teknik latihan asertif terhadap komunikasi interpersonal dan konformitas teman sebaya siswa. Jurnal Kajian Bimbingan dan Konseling, 5(1), 18-23. https://doi.org/10.17977/um001v5i12020p018

Benjamin, A. J. (2016). Aggression. Encyclopedia of mental health: Second edition, 1(2016), 33-39. https://doi. org/10.1016/B978-0-12-397045-9.00198-1

Billstedt, E., Waern, M., Falk, H., Duberstein, P., Östling, S., Hällström, T., \& Skoog, I. (2016). Time trends in Murray's psychogenic needs over three decades in Swedish 75-year-olds. Gerontology, 63(1), 45-54. https:// doi.org/10.1159/000448113

Boger, E., Ellis, J., Latter, S., Foster, C., Kennedy, A., Jones, F., ... Demain, S. (2015). Self-management and self-management support outcomes: A systematic review and mixed research synthesis of stakeholder views. Journal of Plos One, 10(7), 1-25. https://doi.org/10.1371/journal.pone.0130990

Branje, S. (2018). Development of parent-adolescent relationships: Conflict interactions as a mechanism of change. Child Development Perspectives, 12(3), 171-176. https://doi.org/10.1111/cdep.12278

Creswell, J. W. (2012). Educational research: Planning, conducting, and evaluating quantitative and qualitative research. Educational Research (Vol. 4). https://doi.org/10.1017/CBO9781107415324.004

Curry, S. J., \& Whitlock, E. P. (2015). Behavioral counseling interventions expert forum: Overview and primer on U.S. preventive services task force methods. American Journal of Preventive Medicine, 49(3), 129-137. https://doi.org/10.1016/j.amepre.2015.04.017 
Despina, B., Massimiliano, O., Natalie, C., Johanne, R., Tina, M., Michel, B., \& Frank, V. (2020). Cannabis use, depression and suicidal ideation in adolescence: direction of associations in a population based cohort Bolanis. Journal of Affective Disorder, 274(September 2020), 1076-1083. https://doi.org/10.1016/j.jad.2020.05.136

Dharsana, I. K., Sudarsana, G. N., Suarni, N. K., Paramartha, W. E., Tirka, I. W., \& Rismawan, K. S. G. (2019, December). Cognitive counseling with reframing techniques to intervene in self aggression. In 5th International Conference on Education and Technology (ICET 2019). Atlantis Press.

Diastuti, N. P. N., Putri D. A. W. M., \& Dharsana, I. K. (2017). Influence of social cognitive cooperation model with techniques of cognitive restructuring and engineering modeling on self abasement students. Bisma The Journal of Counseling, 1(2), 48. https://doi.org/10.23887/128212017

Dulaney, E. S., Graupmann, V., Grant, K. E., Adam, E. K., \& Chen, E. (2018). Taking on the stress-depression link: Meaning as a resource in adolescence. Journal of Adolescence, 65(2018), 39-49. https://doi.org/10.1016/j. adolescence.2018.02.011

Elvina, S. N. (2019). Teknik self management dalam pengelolan strategi waktu kehidupan pribadi yang efektif. Islamic Counseling: Jurnal Bimbingan dan Konseling Islam, 3(2), 123-138. https://doi.org/10.29240/jbk. v3i2.1058

Fahmi, J. Z., Ramli, M., \& Hidayah, N. (2019). Teknik self-management sebagai upaya mereduksi gaya hidup hedonis siswa SMA. Jurnal Pendidikan: Teori, Penelitian, \& Pengembangan, 4(10), 1408-1416. https://doi. org/10.17977/jptpp.v4i10.12887

Fall, K. A., Holden, J. M., \& Marquis, A. (2017). Theoretical models of counseling and psychotherapy. Taylor \& Francis.

Fuspita, H., Susanti, H., \& Eka Putri, D. (2018). The influence of assertiveness training on depression level of high school students in Bengkulu, Indonesia. Enfermeria Clinica, 28, 300-303. https://doi.org/10.1016/S11308621(18)30174-8

Gading, I. K., Nisa, U., \& Lestari, L. P. S. (2017). Keefektifan konseling behavioral teknik modeling dan konseling analisis transaksional teknik role playing untuk meminimalkan kecenderungan perilaku agresif siswa sekolah menengah atas. Jurnal Kajian Bimbingan dan Konseling, 2(4), 132-142.

Goldberg, D. M., Cho, B. Y., \& Lin, H. C. (2019). Factors influencing U.S. physicians' decision to provide behavioral counseling. Preventive Medicine, 119(November 2018), 70-76. https://doi.org/10.1016/j.ypmed.2018.12.015

Grady, P. A., \& Gough, L. L. (2018). Self-management: A comprehensive approach to management of chronic conditions. American Journal of Public Health, 108(8), 430-436. https://doi.org/10.2105/AJPH.2014.302041

Grossman, D. C., \& Elder, R. W. (2015). Aligning the work of two U.S. task forces on behavioral counseling recommendations. American Journal of Preventive Medicine, 49(3), 174-183. https://doi.org/10.1016/j. amepre.2015.06.003

Itahashi, T., Okada, N., Ando, S., Yamasaki, S., Koshiyama, D., Morita, K., ... Hashimoto, R. ichiro. (2020). Functional connectomes linking child-parent relationships with psychological problems in adolescence. NeuroImage, 219 (2020), 117013. https://doi.org/10.1016/j.neuroimage.2020.117013

Jiménez, T. I., \& Estévez, E. (2017). School aggression in adolescence : Examining the role of individual , family and school variables. International Journal of Clinical and Health Psychology, 17(3), 251-260. https://doi. org/10.1016/j.ijchp.2017.07.002

Jonkman, N. H., Westland, H., Groenwold, R. H. H., Ågren, S., Atienza, F., Blue, L., ... Hoes, A. W. (2016). Do self-management interventions work in patients with heart failure? An individual patient data meta-analysis. Journal of Circulation, 133(12), 1189-1198. https://doi.org/10.1161/CIRCULATIONAHA.115.018006

Kahya, H. H., \& Raspin, C. G. (2017). Yoga therapy for the mind eight-week course: Participants' experiences. Explore: The Journal of Science and Healing, 13(2), 116-123. https://doi.org/10.1016/j.explore.2016.12.006

Kovary, Z. (2018). Personology (Murray). In Encyclopedia of personality and individual differences (pp. 1-10). Cham: Springer International Publishing. https://doi.org/10.1007/978-3-319-28099-8_1149-2

Kurth, A. E., Miller, T. L., Woo, M., \& Davidson, K. W. (2015). Understanding research gaps and priorities for improving behavioral counseling interventions: Lessons learned from the U.S. preventive services task force. American Journal of Preventive Medicine, 49(3), 158-165. https://doi.org/10.1016/j.amepre.2015.06.007

Laura, R. H. (2016). Dialectical behavior theory. In D. Capuzzi \& D. S. Mark (Eds.), Psychotherapy theories and interventions. United States of America: American Counseling Association.

Lundin, A., Stoetzer, U., Modig, K., Carlsson, A. C., Wändell, P., \& Theobald, H. (2014). Personality measured as Murray's psychological needs and all-cause mortality: 41years of follow-up of a population-based sample. Personality and Individual Differences, 68(2014), 32-36. https://doi.org/10.1016/j.paid.2014.04.002 
Michelle, N. L., Wayan, I. S., \& Tirtayani, L. A. (2016). Pengaruh teknik shaping dengan positive reinforcement terhadap kecemasan berpisah pada anak. Jurnal Pendidikan Anak Usia Dini Undiksha, 4(1). https://doi. org/10.23887/paud.v4i1.7534

Mntlangula, M. N., Khuzwayo, N., \& Taylor, M. (2017). Perceptions about their behavioural counselling for HIV / AIDS , STIs and TB in eThekwini Municipality clinics KwAZulu-Natal, South Africa. Health SA Gesondheid, 22(2017), 52-60. https://doi.org/10.1016/j.hsag.2016.09.001

Monica, M. A., \& Gani, R. A. (2016). Efektivitas layanan konseling behavioral dengan teknik self-management untuk mengembangkan tanggung jawab belajar pada peserta didik kelas XI SMAAl-Azhar 3 Bandar Lampung tahun ajaran 2015/2016. KONSELI: Jurnal Bimbingan dan Konseling (E-Journal), 3(2), 119-132.

Murray, H. A. (2008). Exploration of personality. New York: Oxford University Press.

Niusha, B., Farghadani, A., \& Safari, N. (2012). Effects of assertiveness training on test anxiety of girl students in first grade of guidance school. Procedia - Social and Behavioral Sciences, 46(1976), 1385-1389. https://doi. org/10.1016/j.sbspro.2012.05.307

Omura, M., Maguire, J., Levett-Jones, T., \& Stone, T. E. (2017). The effectiveness of assertiveness communication training programs for healthcare professionals and students: A systematic review. International Journal of Nursing Studies, 76(2017), 120-128. https://doi.org/10.1016/j.jjnurstu.2017.09.001

Paeezy, M., Shahraray, M., \& Abdi, B. (2010). Investigating the impact of assertiveness training on assertiveness, subjective well-being and academic achievement of Iranian female secondary students. Procedia: Social and Behavioral Sciences, 5(2010), 1447-1450. https://doi.org/10.1016/j.sbspro.2010.07.305

Parray, W. M., \& Kumar, S. (2016). Assertiveness among undergraduate students of the university. The International Journal of Indian Psychology, 4(1), 283-291.

Pfafman, T. (2017). Assertiveness. In V. Zeigler-Hill \& T. K. Shackelford (Eds.), Encyclopedia of Personality and Individual Differences. Cham: Springer International Publishing. https://doi.org/10.1007/978-3-319-28099-8

Prabowo, A. S., \& Asni, A. (2018). Latihan asertif: Sebuah intervensi yang efektif. Insight: Jurnal Bimbingan Konseling, 7(1), 116-120. https://doi.org/10.21009/insight.071.10

Putra, I. K. B. R. N. A., Suarni, N. K., \& Dharsana, I. K. (2018). Pengaruh teori konseling behavioral dengan tehnik modeling setting lesson study terhadap self endurance siswa kelas X Akomodasi Perhotelan 5 SMK Negeri 2 Singaraja. Bisma The Journal of Counseling, 2(2), 76-82.

Rahayu, E. (2018). Analisis kebutuhan dan profil kepribadian pada orang-orang pengidap HIV/AIDS (Tinjauan dari Edward Personality Preference Schedule). Psikodimensia, 17(1), 43. https://doi.org/10.24167/psidim. v17i1.1071

Sarifa, A. W., \& Mahanani, F. K. (2020). Callous unemotional traits dan perundungan maya pada remaja (Callous unemotional traits and cyberbullying in adolescents). Intuisi: Jurnal Psikologi Ilmiah, 12(1), 103-112.

Smith, C., Cossette, L., Melançon, F., Beauvais-Dubois, C., Smolla, N., Gagnon-Oosterwaal, N., ... Bégin, J. (2018). Behavior problems in adolescence among international adoptees, pre-adoption adversity, and parenting stress. Journal of Applied Developmental Psychology, 57(October 2017), 53-61. https://doi.org/10.1016/j. appdev.2018.04.005

Sucipto, N. H., \& Saleh, A. R. (2019). Individual needs terhadap subjective well-being. Tazkiya Journal of Psychology, 7(1), 42-48.

Syafruddin, Y., Hutabarat, L. T., Novalina, S. D., \& Sinaga, Y. (2016). Profil kebutuhan psikologis taruna / i akademi teknik dan keselamatan penerbangan Medan. Jurnal Diversita, 2(2), 1-13. https://doi.org/doi. org/10.31289/diversita.v2i 2.515

Tuapattinaja, J. M. R., \& Juliana, I. S. (2016). Gambaran profil EPPS pada mahasiswa USU. PSIKOLOGIA: Jurnal Pemikiran \& Penelitian Psikologi, 11(1), 37-46.

Villaggi, B., Provencher, H., Coulombe, S., Meunier, S., Radziszewski, S., Hudon, C., ... Houle, J. (2015b). Selfmanagement strategies in recovery from mood and anxiety disorders. Global Qualitative Nursing Research, 2, 233339361560609. https://doi.org/10.1177/2333393615606092

Wahyu, A. D., \& Muslikah. (2019). Hubungan antara konsep diri dengan perilaku asertif siswa kelas XI. Jurnal Bimbingan Konseling, 5(2), 168-182.

Warburton, W. A., \& Anderson, C. A. (2015). Aggression, social psychology of. International encyclopedia of the social \& behavioral sciences, 1, 373-380.

Xu, X., Mellor, D., \& Read, S. J. (2017). Taxonomy of psychogenic needs (Murray). Journal of Encyclopedia of Personality and Individual Differences, 1-9. https://doi.org/10.1007/978-3-319-28099-8 
Xu, X., Mellor, D., Xu, Y., \& Duan, L. (2014). An update of Murrayan needs: A pilot study among American college students. Journal of Humanistic Psychology, 54(1), 45-65. https://doi.org/10.1177/0022167812470870

Zinn, M. E., Huntley, E. D., \& Keating, D. P. (2020). Resilience in adolescence: Prospective self moderates the association of early life adversity with externalizing problems. Journal of Adolescence, 81(2020), 61-72. https://doi.org/10.1016/j.adolescence.2020.04.004 